\title{
Vitamin D deficiency and insulin resistance
}

\author{
Deficienţa de vitamină $D$ şi rezistenţa la insulină \\ Daniela MIRICESCU ${ }^{1}$, Alexandra TOTAN ${ }^{1}$, Ana Maria Alexandra STĂNESCU ${ }^{2}$, \\ Iulia-loana STĂNESCU ${ }^{1}$, Constantin ȘTEFANI ${ }^{2,3}$, Maria GREABU $^{1}$ \\ ${ }^{1}$ Disciplina Biochimie, Facultatea de Medicină Dentară, \\ Universitatea de Medicină și Farmacie „Carol Davila“, București, România \\ 2Departamentul Medicină de Familie, Universitatea de Medicină și Farmacie „Carol Davila“, \\ București, România \\ ${ }^{3}$ Spitalul Universitar de Urgență Militar Central „Dr. Carol Davila“, București, România
}

\begin{abstract}
Vitamin D or cholecalciferol is active in the human body after two hydroxylation reactions. Once activated, it is involved in bone metabolism, but can also influence other biological processes such as cell growth and proliferation or angiogenesis. Studies conducted so far suggest a link between vitamin $D$ deficiency and insulin resistance. The purpose of this review is to analyze the effects of hypovitaminosis $D$ as well as the administration of vitamin $D$ rich supplements on the insulin resistance provided by the specialized literature.
\end{abstract}

Keywords: vitamin D, defficiency, insulin resistance

\section{REZUMAT}

Vitamina D (colecalciferolul) este activă în organismul uman în urma a două reacții de hidroxilare. Odată activată, este implicată în metabolismul osos, dar mai poate influența și alte procese biologice precum creșterea și proliferarea celulară sau angiogeneza. Studii realizate până în prezent sugerează o legătură între deficiența de vitamină $D$ și rezistența la insulină. Scopul acestui review este de a analiza efectele hipovitaminozei $D$, dar și ale administrării de suplimente bogate în vitamină $D$ asupra rezistenței la insulină, prin intermediul datelor furnizate de literatura de specialitate.

Cuvinte cheie: vitamina D, deficiență, rezistență la insulină

\section{INTRODUCERE}

În ultimul deceniu, foarte multe studii s-au realizat pentru a elucida rolurile vitaminei $D$ în organismul uman. Aceste studii au demarat în secolul
XIX, mai exact în anul 1822, cand dr. Jedrzej Sniadecka a observat faptul că lipsa expunerii la soare contribuie la apariția rahitismului. În secolul XX, Edward Mellasy a relatat că administrarea de ulei de ficat de cod prezintă efecte benefice în tratarea 
și prevenirea rahitismului. Odată cu identificarea receptorului specific vitaminei D (VDR), prezent la nivelul diferitelor tipuri de țesuturi, s-a observat o legătură între deficiența de vitamină D și o incidență crescută a unor afecțiuni precum: obezitate, rezistență la insulină, sindrom metabolic, diabet zaharat tip 2, risc cardiovascular, depresie, afecțiuni neoplazice [1-3].

\section{ROLURI FIZIOLOGICE ALE VITAMINEI D}

Termenul de vitamina D se referă la cele două forme majore ale sale: vitamina $D_{2}$ (ergocalciferol) și vitamina $\mathrm{D}_{3}$ (colecalciferol), cu două forme active: 25 -hidroxivitamina $\mathrm{D}_{3}$ (calcidiolul, $25(\mathrm{OH}) \mathrm{D}$ ) și 1,25-dihidroxivitamina $\mathrm{D}_{3}$ (calcitriolul, 1,25- $(\mathrm{OH})_{2}$ $D_{3}$ ). Sub acțiunea radiaților ultraviolete (UVB, 290$315 \mathrm{~nm}$ ), 7-dehidrocolesterol este transformat în provitamina $\mathrm{D}_{3}$ la nivelul pielii, care, la rândul său, este transformată în urma a două reacții de hidroxilare în calcitriol. Vitamina D circulă în organismul uman legată de o proteină de legare specifică (DBP-vitamin D binding protein), care o transportă la ficat, unde 25-hidroxilaza-vitamina D introduce o grupare hidroxil în poziția 25 cu formare de 25 $(\mathrm{OH})$ D. Această formă este hidroxilată din nou la nivelul rinichilor, cu formare de $1,25-(\mathrm{OH})_{2} \mathrm{D}_{3^{\prime}}$, reacție catalizată de către enzima 25-hidroxivitamina D-1 alfa-hidroxilaza (CYP27B1). Prezența CYP27B1 în mai multe tipuri de țesuturi care exprimă și VDR sugerează că această vitamină ar putea manifesta și alte roluri în afară de metabolismul osos. în forma sa activă, vitamina D exercită roluri la nivelul scheletului, favorizând formarea cristalelor de hidroxiapatită, la nivelul intestinului subțire favorizează absorbția de $\mathrm{Ca}^{2+}$, iar la nivel renal favorizează reabsorbția renală de $\mathrm{Ca}{ }^{2+}$, scăzând fosfaturia [4,5]. Forma biologic activă 1,25- $(\mathrm{OH})_{2} \mathrm{D}_{3}$ se leagă de VDR, acesta formând un heterodimer cu receptorul vitaminei A RXR (RXR-retinoid receptor). Complexul format, 1,25- $(\mathrm{OH})_{2} \mathrm{D}_{3}-\mathrm{VDR}-\mathrm{RXR}$, este translocat în nucleu, unde se leagă de VDRE (vitamin $D$ responsive elements) în regiunea promotor a genelor responsabile pentru vitamina $D$. În urma interacțiunii complexului format cu VDRE, are loc activarea unor complexe enzimatice responsabile pentru remodelarea cromatinei, facilitând modificarea epigenică a histonelor, dar și recrutarea ARN polimerazei II. Aceste schimbări pozitive sau negative reglează pozitiv sau negativ expresia unor gene țintă, incluzând gene pentru proliferare și diferențiere celulară, activitate imunomodulatorie și angiogeneză [6]. Vitamina D prezintă și activitate nongenomică, manifestată prin activarea a numeroase molecule de semnalizare precum fosfatidil-inozitol 3-kinaza, fosfolipaza C, Ca-calmodulina kinaza II, proteinkinaza A și C. Calcitriolul este implicat, de asemenea, în generarea mesagerilor secundari, AMPc, $\mathrm{Ca}^{2+}$, acizi grași, 3-fosfatidilinozitolul [7]. Interesul pentru vitamina D a crescut foarte mult, astfel, în anii 2000-2010, s-au realizat numeroase studii pentru a se cunoaște concentrația serică normală, crescând în același timp și cererea pentru suplimente de vitamină. Indicatorul nivelului de vitamină $D$ este reprezentat de concentrația metabolitului său circulant 25 $(\mathrm{OH}) \mathrm{D}$, al cărui timp de înjumătățire este de 10-19 zile. Concentrația 25(OH)D reflectă concentrația vitaminei $D$ care există în organism uman. Mai multe instituții și societăți de specialitate, inclusiv Societatea Americană de Endocrinologie, au elaborat ghiduri privind concentrațiile optime de vitamină D, după cum se poate observa din Tabelul 1 [8].

TABEL 1. Concentrațiile 25(OH)D

\begin{tabular}{|c|c|l|}
\hline $\begin{array}{c}\text { Concentrație } \\
\text { calcidiol (nmol/l) }\end{array}$ & $\begin{array}{c}\text { Concentrație } \\
\text { calcidiol (ng/ml) }\end{array}$ & \multicolumn{1}{|c|}{ Clasificare } \\
\hline$<50$ & $<20$ & De ță \\
\hline $50-80$ & $20-32$ & \multicolumn{1}{c|}{ ță } \\
\hline $135-225$ & $54-90$ & Normal \\
\hline$>250$ & $>100$ & Exces \\
\hline$>325$ & $>150$ & Intoxicație \\
\hline
\end{tabular}

Într-o proporție de 85-90\%, de proteina specifică vitaminei D VDBP (vitamin D binding protein) se leagă formele circulante, și anume 25 (HO)D și $1,25(\mathrm{OH})_{2} \mathrm{D}_{3}$. Diferența de $10-15 \%$ de $25-\mathrm{HOD}$ se leagă de albumină, $1 \%$ rămânând liberă [9]. Un studiu realizat recent a observat faptul că populația de culoare prezintă niveluri scăzute de VDBP și 25(HO)D, comparativ cu populația albă [10]. O supradoză de vitamina $D$ conduce la intoxicație, care va avea drept consecință instalarea hipercalcemiei, care se manifestă prin sete, slăbiciune musculară, poliurie, nefrocalcinoză și insuficiență renală [11]

\section{VITAMINA D ŞI DIABETUL ZAHARAT DE TIP 2}

Diabetul zaharat de tip 2 (DZ 2) este, din nefericire, din ce în ce mai frecvent atât la nivel național, cât și la nivel mondial. Organizația Mondială a Sănătății a raportat că $90 \%$ dintre cazurile de diabet existent sunt reprezentate de DZ2 și aproximativ 15 milioane din populația globului suferă de DZ2. Mai mult, acest număr ar putea fi dublat până în 2025. Următoarele dezechilibre metabolice precum inflamația sistemică, perturbări ale căilor de semnalizare ale insulinei și ale celulelor $\beta$-pancreatice sunt implicate atât în rezistența la 
insulină, cât și în dezvoltarea DZ2. În prezent, deficiența de vitamina $D$ pare a fi frecvent legată de patogeneza numeroaselor afecțiuni sistemice, fiind propusă o asociere între deficiența de vitamină și rezistența la insulină $[12,13]$.

Insulina este un reglator major al metabolismului glucidic și lipidic. Creșterea concentrației sangvine de glucoză conduce la secreția de insulină, glucoza putând pătrunde în celulele $\beta$-pancreatice cu ajutorul transportorului de glucoză -2 (Glut -2). în continuare, glucoza este convertită în urma degradării aerobe (glicoliză aerobă, ciclul Krebs și lanțul respirator mitocondrial) la ATP. Un nivel crescut de ATP inhibă canalul de K, care este ATP-sensibil, conducând la depolarizarea membranei și determină deschiderea canalelor dependente de voltaj (tip L) și eliberarea $\mathrm{Ca}^{2+}$ intracelular și, în final, secreția de insulină $[14,15]$.

În mod normal, rolul insulinei este inițiat prin legarea de receptorul său specific (IR-insulin receptor), care prezintă activitate tirozin kinazică. După legarea la IR, receptorul suferă auto-fosforilare, fosforilând mai departe substratul receptorului insulinic (IRS-insulin receptor substrate), care, odată fosforilat, activează fosfatidil-inozitolul-3-kinaza. În continuare, această kinază fosforilează fosfatidil-inozitol-4,5 bisfosfatul $\left(\right.$ PIP $\left._{2}\right)$ la fosfatidilinozitol 3, 4, 5 trifosfatul $\left(\mathrm{PIP}_{3}\right)$. PIP ${ }_{3}$ activează PDK1 (phosphoinositol-dependent protein kinase-1), care, în continuare, va fosforila și activa proteinkinaza C și B (cunoscută ca AKT). AKT, odată activată, va determina translocarea Glut-4 la nivel membranei plasmatice pentru captarea glucozei. Protein kinaza B sau AKT activată prin procese de fosforilare stimulează sinteza de proteine, glicogeneza, lipogeneza, inhibă lipoliza, glicogenoliza, gluconeogeneza și proteoliza $[16,17]$. În cazul rezistenței la insulină, numeroase proteinkinaze, precum JNK (c-Jun N-terminal kinases), blochează IRS. Astfel, cascada reacțiilor de fosforilare este blocată și nu mai are loc translocarea Glut-4 la nivelul membranelor celulare. Celulele $\beta$-pancreatice suferă modificări, conducând la eliberarea unor cantități mari de insulină, hiperinsulinemia instalată va determina apariția DZ2 în procent de 60\% [18-20]. Rezistența la insulină este strâns corelată cu obezitatea, care, la rândul ei, este asociată cu stresul oxidativ și un nivel inflamator crescut $[18,21]$. Deficiența de vitamină D poate fi implicată în patogeneza dezechilibrelor metabolice care determină instalarea hiperglicemiei și a obezității [22].

Rezultatele a numeroase studii observaționale au relatat că hipovitaminoza D favorizează dezvoltarea rezistenței la insulină, nivelurile serice de vitamina D corelându-se cu IMC, TG (trigliceridele),
HDL (lipoproteine cu densitate mare), LDL (lipoproteine cu densitate mică) și HbA1c. Sunt studii care confirmă efecte benefice ale suplimentelor cu vitaminei $D$, dar și studii care nu au observat niciun impact al vitaminei $D$ asupra parametrilor asociați cu rezistența la insulină în cazul pacienților cu DZ2 sau la cei cu prediabet [23-28]. Unele studii clinice au arătat că suplimentarea cu vitamina $D$ reduce nivelul unor parametri precum colesterolul total, LDL, TG, HbA1c, precum și a indicatorului de rezistență la insulină - HOMA-IR la pacienții cu DZ2 [29,30].

$\mathrm{Cu}$ toate acestea, nu este pe deplin cunoscut modul în care vitamina $D$ poate reduce riscul de dezvoltare a tulburărilor metabolice. Recent, VDR și enzimele metabolizante de vitamina $D$ au fost detectate în diferite tipuri de celule, inclusiv celule $\beta$-pancreatice și celule sensibile la insulină, precum adipocitele. Tesutul adipos este principalul organ de depozitare a vitaminei $D$ și o sursă importantă de adipokine și citokine care participă la instalarea inflamației sistemice. Este cunoscut faptul că obezitatea, în special cea viscerală, este unul dintre factorii de risc majori pentru DZ2. Deficiența de vitamină $D$ poate fi elementul de legătură între diabet și obezitate [31,32].

Vitamina $D$ reglează numeroasele evenimente metabolice care permit celulelor $\beta$-pancreatice să secrete insulină, controlând astfel nivelului glicemiei. Atât studiile realizate in vitro, cât și cele in vivo au raportat că vitamina $D$ poate juca un rol important în menținerea funcției celulelor $\beta$-pancreatice [33]. Acest efect ar putea avea explicații diferite. Ar putea fi indusă de activarea VDR localizat la nivelul celulelor $\beta$-pancreatice. Zeitz U. și colaboratorii au observat cum șoarecilor fără VDR le-a fost afectată secreția de insulină și adăugarea de calcitriol la mediul de cultură a stimulat insulele pancreatice să secrete insulină. Mai mult, vitamina D ar putea influența și secreția de insulină prin reglarea deschiderii și închiderii canalelor de $\mathrm{Ca}^{2+}[34,35]$.

Calcitriolul participă ca un mesager chimic care interacționează cu diferiți receptori și reglează concentrația de $\mathrm{Ca}^{2+}$ în celulele $\beta$-pancreatice. Din acest motiv, $\mathrm{Ca}^{2+}$ este esențial pentru secreția de insulină, astfel, o deficiență de vitamină $D$ poate modifica secreția normală de insulină prin modificări ale fluxului de $\mathrm{Ca}^{2+}$ în celulele $\beta$ [36]. Studii preclinice realizate arată că vitamina $D$ poate reduce hiperactivitatea sistemului angiotensină-renină și, astfel, poate îmbunătăți funcționarea celulelor $\beta$-pancreatice [37].

Un nivel normal de vitamină $D$ poate îmbunătăți mecanismele rezistenței la insulină asociate cu di- 
abetul. Această rezistență este cauzată în principal de modificări ale fluxului și concentrației de $\mathrm{Ca}^{2+}$ prin membranele celulare ale țesuturilor sensibile la insulină [38]. Reglarea concentrațiilor de $\mathrm{Ca}^{2+}$ extracelulare și intracelulare poate favoriza defosforilarea transportorului de glucoză-4 (GLUT-4) conducând la un transport redus de glucoză. $1,25(\mathrm{OH})_{2} \mathrm{D}_{3}$ stimulează expresia receptorilor de insulină, stimulând astfel și sensibilitatea la insulină [39].

În plus, calcitriolul îmbunătățește sensibilitatea la insulină activând receptorul delta asociat cu proliferarea peroxisomală (PPAR-d), un factor de transcripție care reglează metabolismul acizilor grași de la nivelul țesutul adipos și al mușchiul scheletic. Un alt studiu interesant condus de către Leung PS și colaboratorii indică faptul că rezistența la insulină poate fi redusă prin efectele specifice ale calcitriolului asupra sintezei lipidelor hepatice și a glucozei [37].

Calcitriolul prezinta un rol central într-o mare varietate de căi metabolice prin legarea la VDR, iar măsurarea $25(\mathrm{OH}) \mathrm{D}$ este un biomarker important pentru evaluarea riscurilor de sănătate. Acest receptor este exprimat de numeroase celule, precum celulele $\beta$-pancreatice, dar și de celule din ficat, țesut adipos și țesut muscular. VDR și 1 $\alpha$-hidroxilaza, enzima care catalizează conversia calcidiolul în calcitriolului, sunt exprimate în preadipocite primare și adipocite recent diferențiate. Studii in vitro sugerează faptul că același calcitriol reglează creșterea și remodelarea țesutul adipos. Țesutul adipos este țesut pentru stocarea de vitamină $D[40,41]$.

Un IMC crescut se asociază cu concentrații scăzute de vitamină D. Jucând rol de hormon liposolubil, vitamina $\mathrm{D}$ este reținută în țesutul adipos, fiind disponibile mici cantități pentru circulație. Concentrația serică de $25(\mathrm{OH}) \mathrm{D}$ și țesutul adipos sunt strâns corelate, astfel că obezitatea poate reduce concentrația serică de $25(\mathrm{OH}) \mathrm{D}$ prin diluarea volumetrică și bio-distribuția $25(\mathrm{OH}) \mathrm{D}$ într-un volum mai mare de țesut adipos $[42,43]$. Vitamina D ar putea reduce și efectele inflamației cronice, jucând astfel un rol cheie în patogeneza DZ2. Calcitriolul poate proteja împotriva apoptozei induse de citokine din celulelor $\beta$-pancreatice, reglând în mod direct activitatea și expresia citokinelor, cu o îmbunătățire a sensibilității la insulină [44]. În urma realizării de studii experimentale, s-a observat că vitamina $D$ reduce acumularea produșilor de glicare avansată, specifici dezvoltării DZ. Acești produși sunt implicați în dezvoltarea complicațiilor DZ2 și au fost asociați cu rezistența la insulină [45].
Park și colaboratorii au măsurat concentrațiile de $25(\mathrm{OH})$ D într-o cohortă de 903 adulți fără diabet sau prediabet, observând o relație indirectă răspuns-doză între concentrația $25(\mathrm{OH}) \mathrm{D}$ și riscul de diabet. Ei au propus o concentrație țintă pentru $25(\mathrm{OH}) \mathrm{D}$ de $50 \mathrm{ng} / \mathrm{ml}$, mult mai mare decât concentrațiile sugerate în alte studii, în încercarea de a influența și de a reduce rata apariției DZ [46]. Aceste date sunt în concordanță cu concentrațiile publicate de Avila-Rubio și colaboratorii la femeile aflate în postmenopauză, autorii observând că valori ale $25(\mathrm{OH}) \mathrm{D}$ mai mari de $45 \mathrm{ng} / \mathrm{dl}$ la aceste femei se asociază cu indice glicemic bun [47].

Sollid ST și colaboratorii au efectuat un studiu clinic randomizat pe 500 de subiecți prediabetici, comparând efectele vitamina $D$ versus placebo pentru prevenirea DZ2. Ei au administrat un supliment cu 20.000 UI de colecalciferol săptămânal și, după un an, nu au raportat diferențe semnificative între subiecții care au primit vitamina $D$ și cei care au luat placebo, evidențiat prin determinarea biomarkerilor specifici metabolismului glicemic și ai inflamației și măsurarea tensiunii arteriale [48].

Forouhi NG și colaboratorii au comparat, întrun alt studiu randomizat, format din 340 voluntari cu prediabet sau cu risc de a dezvolta DZ2, efectul suplimentării cu colecalciferol sau ergocalciferol (ambele fiind de 100.000 UI/lună) față de placebo, pe o perioada de patru luni. În ciuda suplimentării cu vitamina $D$, nici ergocalciferolul, nici colecalciferolul nu au condus la creșterea concentrațiilor de $25(\mathrm{OH}) \mathrm{D}_{2}$ și $1,25(\mathrm{OH})_{2} \mathrm{D}_{3}$. Nu au existat diferențe serice în concentrația de $\mathrm{HbA1}$ c între grupuri. Este important de subliniat că doar jumătate dintre subiecți au avut concentrații de $25(\mathrm{OH}) \mathrm{D}<50$ nmol/l [49]. Gagnon și colaboratorii au raportat la subiecți cu prediabet o îmbunătățire a indicilor de sensibilitate la insulină. Anterior, au administrat zilnic un supliment alcătuit din carbonat de calciu (1.200 mg) și colecalciferol (2.000-6.000 UI) subiecților cu intoleranță la glucoză sau diabet diagnosticat recent. Nu au observat niciun efect asupra sensibilității sau secreției de insulină sau asupra funcției celulelor $\beta$-pancreatice [50]. Mitri J. și colaboratorii au raportat în anul 2011 o îmbunătățire semnificativă a secreției de insulină la 92 de subiecți prediabetici care erau supraponderali sau obezi și prezentau risc crescut de a dezvolta DZ2. Lotul analizat a primit suplimente cu colecalciferol $2.000 \mathrm{UI}$ zilnic și carbonat de calciu versus un lot care a primit placebo timp de patru luni [51]. Se poate rezuma, astfel, că vitamina $D$ poate fi un potențial reglator al secreției de insulină, al nivelului de $\mathrm{Ca}^{2+}$ și al supraviețuirii celulelor 
$\beta$-pancreatice. Calcitriolul poate stimula direct secreția de insulină, deoarece VDRE a fost identificat în regiunea promotor a genei pentru insulină. Acesta induce nu numai transcripția genei pentru insulină, dar și a altor gene implicate în organizarea citoscheletului, a joncțiunilor intracelulare și creșterea celulară a celulelor $\beta$-pancreatice [52].

\section{CONCLUZIE}

Chiar dacă rezultatele studiilor realizate până în prezent sunt contradictorii, administrarea de suplimente cu vitamina D prezintă efecte benefice în rândul populației sănătoase pentru prevenirea DZ2.

\section{Mențiune}

Toți autorii au contribuit în mod egal la scrierea manuscrisului.

\section{Conflict of interest: none declared} Financial support: none declared

\section{BIBLIOGRAFIE}

1. Littlejohns TJ, Henley WE, Lang IA et al. Vitamin $D$ and the risk of dementia and Alzheimer disease. Neurology 2014; 83(10):920-928.

2. Bischoff-Ferrari $H A$, Borchers $M$, Gudat $F$ et al. Vitamin $D$ receptor expression in human muscle tissue decreases with age. J Bone Miner Res 2004; 19(2):265-269.

3. Garland CF, Garland FC, Gorham ED et al. The role of vitamin $D$ in cancer prevention. Am J Public Health 2006; 96(2):252-261.

4. Zeitz U, Weber K, Soegiarto DW et al. Impaired insulin secretory capacity in mice lacking a functional vitamin $D$ receptor. FASEB J 2003; 17: 509-511.

5. Bouillon R, Carmeliet G, Verlinden L et al. Vitamin $D$ and human health: Lessons from vitamin D receptor null mice. Endocr Rev 2008; 29: 726-776.

6. Pike JW, Meyer MB. Fundamentals of vitamin $\mathrm{D}$ hormone-regulated gene expression. J Steroid Biochem Mol Biol 2014; 144: 5-11.

7. Hii CS, Ferrante A. The Non-Genomic Actions of Vitamin D. Nutrients 2016; 8 : 135.

8. Alshahrani F, Aljohani N. Vitamin D: Deficiency, Su $\square$ ciency and Toxicity. Nutrients 2013; 5: 3605-3616.

9. Brown AJ, Coyne DW . Bioavailable vitamin $\mathrm{D}$ in chronic kidney disease. Kidney Int 2012; 82(1):5-7.

10. Powe CE, Evans MK, Wenger J et al. Vitamin D-binding protein and vitamin $\mathrm{D}$ status of black Americans and white Americans. New Engl J Med 2013; 369(21):1991-2000.

11. Galior K, Grebe S, Singh R. Development of vitamin $D$ toxicity from overcorrection of vitamin $D$ deficiency: a review of case reports. Nutrients 2018; 10(8):953.

12. Wang $H$, Chen W, Li D et al. Vitamin D and Chronic Diseases. Aging Dis 2017; 8: 346-353.

13. Tao $S$, Yuan $Q$, Mao $L$ et al. Vitamin D deficiency causes insulin resistance by provoking oxidative stress in hepatocytes. Oncotarget 2017; 8: 67605-67613.

14. Saltiel AR, Kahn CR. Insulin signalling and the regulation of glucose and lipid metabolism. Nature 2001; 414: 799-806.
15. Nicholls DG. The Pancreatic $\beta$-Cell: A Bioenergetic Perspective. Physiol Rev 2016;96:1385-1447.

16. Strycharz J, Drzewoski J, Szemraj J et al. Is p53 Involved in Tissue-Specific Insulin Resistance Formation? Oxid Med Cell Longev 2017; 2017: 9270549.

17. Hers I, Vincent E, Tavare JM. Akt signaling in health and disease. Cell Signal 2011; 23(10): 1515-1527.

18. Chang YC, Chuang LM. The role of oxidative stress in the pathogenesis of type 2 diabetes: From molecular mechanism to clinical implication. Am J Transl Res 2010; 2: 316-331.

19. Butler AE, Janson J, Bonner-Weir S et al. $\beta$-Cell Deficit and Increased $\beta$-Cell Apoptosis in Humans With Type 2 Diabetes. Diabetes 2003; 52: 102-110.

20. Rhodes CJ. Type 2 Diabetes-a Matter of ß-Cell Life and Death? Science 2005; 307: 380-384.

21. Garbossa SG, Folli F. Vitamin D, subinflammation and insulin resistance. A window on a potential role for the interaction between bone and glucose metabolism. Rev Endocr Metab Disord 2017; 18: 243-258.

22. Wimalawansa SJ. Associations of vitamin $D$ with insulin resistance, obesity, type 2 diabetes, and metabolic syndrome. J Steroid Biochem Mol Biol 2018; 175: 177-189.

23. Heaney RP, French CB, Nguyen S et al. A novel approach localizes the association of vitamin $D$ status with insulin resistance to one region of the 25-hydroxyvitamin $D$ continuum. Adv Nutr 2013: 4: 303-310.

24. Dutta D, Maisnam I, Shrivastava A et al. Serum vitamin D predicts insulin resistance in individuals with prediabetes. Indian J Med Res 2013; 138: 853-860.

25. Kayaniyil S, Vieth R, Retnakaran $\mathrm{R}$ et al. Association of vitamin $D$ with insulin resistance and beta-cell dysfunction in subjects at risk for type 2 diabetes. Diabetes Care 2010; 33: 1379-1381.

26. Chiu KC, Chu A, Go VLW et al. Hypovitaminosis $D$ is associated with insulin resistance and beta cell dysfunction. Am J Clin Nutr 2004; 79: 820-825.

27. Forouhi NG, Menon RK, Sharp SJ et al. $\mathrm{E} \square$ ects of vitamin D2 or D3 supplementation on glycaemic control and cardiometabolic risk among people at risk of type 2 diabetes: Results of a randomized double-blind placebo-controlled trial. Diabetes Obes Metab 2016; 18: 392-400.

28. Davidson MB, Duran P, Lee ML et al. High-dose vitamin D supplementation in people with prediabetes and hypovitaminosis D. Diabetes Care 2013; 36: 260-266.

29. Upreti V, Maitri V, Dhull P et al. E $\square$ ect of oral vitamin $\mathrm{D}$ supplementation on glycemic control in patients with type 2 diabetes mellitus with coexisting hypovitaminosis $\mathrm{D}$ : A parellel group placebo controlled randomized controlled pilot study. Diabetes Metab Syndr 2018; 12: 509-512.

30. Mirhosseini N, Vatanparast $\mathrm{H}$, Mazidi M et al. Effect of improved serum 25-hydroxy vitamin $D$ status on glycemic control in diabetic patients: a meta-analysis. J Clin Endocrinol Metab 2017; 102:3097-3110.

31. Abbas M A. Physiological functions of Vitamin D in adipose tissue. J Steroid Biochem Mol Biol 2017; 165: 369-381.

32. Li YX, Zhou L. Vitamin D Deficiency, Obesity and Diabetes. Cell. Mol. Biol. Noisy 2015; 61: 35-38.

33. Cade C, Norman AW. Rapid normalization/ stimulation by 1,25 - dihydroxyvitamin $\mathrm{d} 3$ of insulin secretion and glucose tolerance in the vitamin d-deficient rat. Endocrinology 1987; 120: 1490-1497.

34. Zeitz U, Weber K, Soegiarto DW et al. Impaired insulin secretory capacity in mice lacking a functional vitamin $D$ receptor. FASEB J 2003; 17: 509-511.

35. Bouillon R, Carmeliet G, Verlinden L et al. Vitamin $D$ and human health: Lessons from vitamin D receptor null mice. Endocr Rev 2008; 29: 726-776.

36. Bland R, Markovic D, Hills CE et al. Expression of 25-hydroxyvitamin D3-1alpha-hydroxylase in pancreatic islets. J Steroid Biochem Mol Biol 2004; 89-90: 121-125.

37. Leung PS. The potential protective action of vitamin $D$ in hepatic insulin resistance and pancreatic islet dysfunction in type 2 diabetes mellitus. Nutrients 2016; 8: 147.

38. Wright DC, Hucker KA Holloszy JO et al. $\mathrm{Ca} 2+$ and AMPK both mediate stimulation 
of glucose transport by muscle

contractions. Diabetes 2004; 53: 330-335.

39. Draznin B. Cytosolic calcium and insulin resistance. Am J Kidney Dis 1993; 21: 32-38.

40. Nimitphong $\mathrm{H}$, Holick MF, Fried SK et al. 25-hydroxyvitamin $\mathrm{D}(3)$ and 1,25-dihydroxyvitamin $\mathrm{D}(3)$ promote the differentiation of human subcutaneous preadipocytes. PLoS ONE 2012; 7: e52171.

41. Blum M, Dolnikowski $G$, Seyoum E et al. Vitamin D(3) in fat tissue. Endocrine 2008; 33: 90-94.

42. Wamberg L, Christiansen T, Paulsen SK et al. Expression of vitamin D-metabolizing enzymes in human adipose tissue - The effect of obesity and diet-induced weight loss. Int J Obes 2013; 37: 651-657.

43. Hyppönen E, Boucher BJ. Adiposity, vitamin $D$ requirements, and clinical implications for obesity-related metabolic abnormalities. Nutr Rev 2018; 76: 678-692.

44. Chun RF, Liu PT, Modlin RL et al. Impact of vitamin $D$ on immune function: lessons learned from genome-wide analysis. Front Physiol 2014; 5:151.
45. Salum E, Kals J, Kampus P et al. Vitamin D reduces deposition of advanced glycation end-products in the aortic wall and systemic oxidative stress in diabetic rats. Diabetes Res Clin Pract 2013; 100: 243-249.

46. Park SK, Garland CF, Gorham ED et al. Plasma 25-hydroxyvitamin D concentration and risk of type 2 diabetes and prediabetes: 12-year cohort study. PLOS ONE 2018 13: e0193070.

47. Avila-Rubio V, Garcia-Fontana B, Novo-Rodriguez $C$ et al. Levels of serum 25-hydroxy vitamin $D$ are related to improved glucose homeostasis in women with postmenopausal osteoporosis. J Women's Health 2018: 27:1007-1015.

48. Sollid ST, Hutchinson MYS, Fuskevag OM et al. No effect of high-dose vitamin D supplementation on glycemic status or cardiovascular risk factors in subjects with prediabetes. Diabetes Care 2014; 37: 2123-2131.

49. Forouhi NG, Menon RK, Sharp SJ et al. Effects of vitamin D2 or D3 supplementation on glycaemic controland cardiometabolic risk among people at riskof type 2 diabetes:
Results of a randomized double-blind placebo-controlled trial. Diabetes Obes Metab 2016; 18: 392-400.

50. Gagnon C, Daly RM, Carpentier A et al. Effects of combined calcium and vitamin D supplementation on insulin secretion, insulin sensitivity and beta-cell function in multi-ethnic vitamin D-deficient adults at risk for type 2 diabetes: A pilot randomized, placebo-controlled trial. PLOS ONE 2014; 9: e109607.

51. Mitri J, Dawson-Hughes B, Hu FB et al. Effects of vitamin $D$ and calcium supplementation on pancreatic beta cell function, insulin sensitivity, and glycemia in adults at high risk of diabetes: The Calcium and Vitamin D for Diabetes Mellitus (CaDDM) randomized controlled trial. Am J Clin Nutr 2011; 94: 486-494.

52. Wolden-Kirk H, Overbergh L, Gysemans C et al. Unraveling the effects of $1,25 \mathrm{OH} 2 \mathrm{D} 3$ on global gene expression in pancreatic islets. J Steroid Biochem Mol Biol 2013; 136: 68-79. 